\title{
Soufeng sanjie formula alleviates collagen-induced arthritis in mice by inhibiting Th17 cell differentiation
}

\author{
Di Hua ${ }^{1 \dagger}$, Jie Yang ${ }^{1 \dagger}$, Qinghai Meng ${ }^{2 \dagger}$, Yuanyuan Ling ${ }^{1}$, Qin Wei ${ }^{1}$, Zhigang Wang ${ }^{1}$, Qingyun Wei ${ }^{1}$, Jiao Chen ${ }^{1}$, \\ Juan Ye ${ }^{1}$, Xuan Han ${ }^{1}$, Kelei Su${ }^{1}$, Weikang Kong ${ }^{3}$, Chao Xu ${ }^{1}$, Peng Cao ${ }^{2^{*}}$ and Chunping Hu ${ }^{1 *}$
}

\begin{abstract}
Background: Rheumatoid arthritis (RA) is a chronic autoimmune disease. Soufeng sanjie formula (SF), which is composed of scolopendra (dried body of Scolopendra subspinipes mutilans L. Koch), scorpion (dried body of Buthus martensii Karsch), astragali radix (dried root of Astragalus membranaceus (Fisch.) Bge), and black soybean seed coats (seed coats of Glycine max (L.) Merr), is a traditional Chinese prescription for treating RA. However, the mechanism of SF in treating RA remains unclear. This study was aim to investigate the anti-arthritic effects of SF in a collagen-induced arthritis (CIA) mouse model and explore the mechanism by which SF alleviates arthritis in CIA mice.

Methods: For in vivo studies, female DBA/1J mice were used to establish the CIA model, and either SF (183 or 550 $\mathrm{mg} / \mathrm{kg} /$ day) or methotrexate (MTX, $920 \mathrm{mg} / \mathrm{kg}$, twice/week) was orally administered to the mice from the day of arthritis onset. After administration for 30 days, degree of ankle joint destruction and serum levels of lgG and inflammatory cytokines were determined. The balance of Th17/Treg cells in the spleen and lymph nodes was analyzed using flow cytometry. Moreover, the expression levels of retinoic acid receptor-related orphan nuclear receptor (ROR) $y t$ and phosphorylated STAT3 (pSTAT3, Tyr705) in the spleen were detected by immunohistochemistry. Furthermore, the effect of SF on Th17 cells differentiation in vitro was investigated in $\mathrm{CD}^{+}{ }^{+}$cells under Th17 polarization conditions.

Results: SF decreased the arthritis score, ameliorated paw swelling, and reduced cartilage loss in the joint of CIA mice. In addition, SF decreased the levels of bovine collagen-specific IgG in sera of CIA mice. SF decreased the levels of inflammatory cytokines (TNF-a, IL-6, and IL-17A) and increased the level of IL-10 both in the sera and the joint of CIA mice. Moreover, SF treatment rebalanced the Th17/Treg ratio in the spleen and lymph nodes of CIA mice. SF also reduced the expression levels of ROR yt and pSTAT3 (Tyr705) in the spleen of CIA mice. In vitro, SF treatment reduced Th17 cell generation and IL-17A production and inhibited the expression of RORyt, IRF4, IL-17A, and pSTAT3 (Tyr705) under Th17 polarization conditions.
\end{abstract}

Conclusions: Our results suggest that SF exhibits anti-arthritic effects and restores Th17/Treg homeostasis in CIA mice by inhibiting Th17 cell differentiation.

Keywords: Collagen-induced arthritis, Soufeng sanjie formula, Th17, Th17/Treg, RORYt

*Correspondence: cao_peng@njucm.edu.cn; njhcp66@126.com

†Di Hua, Jie Yang and Qinghai Meng contributed to this work

${ }^{1}$ Affiliated Hospital of Integrated Traditional Chinese and Western Medicine, Nanjing University of Chinese Medicine, Nanjing 210028, China

${ }^{2}$ College of Pharmacy, Nanjing University of Chinese Medicine, Nanjing 210023, China

Full list of author information is available at the end of the article

\section{Background}

Rheumatoid arthritis (RA) is a chronic autoimmune disease in which multiple immune cell types and signaling networks malfunction to elicit a maladaptive tissue repair process that leads to organ damage, predominantly in the

c) The Author(s) 2021. This article is licensed under a Creative Commons Attribution 4.0 International License, which permits use, sharing, adaptation, distribution and reproduction in any medium or format, as long as you give appropriate credit to the original author(s) and the source, provide a link to the Creative Commons licence, and indicate if changes were made. The images or other third party material in this article are included in the article's Creative Commons licence, unless indicated otherwise in a credit line to the material. If material is not included in the article's Creative Commons licence and your intended use is not permitted by statutory regulation or exceeds the permitted use, you will need to obtain permission directly from the copyright holder. To view a copy of this licence, visit http://creativeco mmons.org/licenses/by/4.0/. The Creative Commons Public Domain Dedication waiver (http://creativecommons.org/publicdomain/ zero/1.0/) applies to the data made available in this article, unless otherwise stated in a credit line to the data. 
joints [1]. The most prominent feature of RA is swelling and deformation of the hands, wrists, feet, and knees [2]. RA may occur at any age, and the cumulative lifetime risk of developing adult-onset RA has been estimated at roughly $3.6 \%$ for women and $1.7 \%$ for men, with a peak incidence age of 50 to 60 years [3].

Substantial evidence has emerged supporting a role for immune cells, including $\mathrm{T}$ cells, macrophages, and fibroblasts, as well as inflammatory cytokines, in the initiation and progression of RA $[4,5] . \mathrm{CD}^{+}{ }^{+} \mathrm{T}$ helper (Th) cells regulate immunity and inflammation through antigendependent activation and cytokine-dependent differentiation into functionally distinct effector and regulatory $\mathrm{T}$ cell subsets. The proinflammatory cytokine tumor necrosis factor- $\alpha$ (TNF- $\alpha$ ) regulates Treg cells through Foxp3 dephosphorylation, and interleukin- 6 (IL-6) and TNF- $\alpha$ trigger naïve $\mathrm{CD} 4^{+} \mathrm{T}$ cell differentiation into Th17 cells $[6,7]$. However, the imbalance of regulatory $\mathrm{T}$ cells (Tregs) and Th17 cells can cause autoimmune diseases [8]. Th17 cells have been shown to stimulate fibroblastlike synoviocytes via interleukin-17 (IL-17) and expand synovial-resident innate lymphoid cells in inflamed joints [9]. Therefore, the inhibition of Th17 cell activity and IL-17 expression has become a potential therapeutic target for the treatment of RA.

The current drugs for the treatment of RA are mainly conventional synthetic agents (e.g., methotrexate) and targeted synthetic disease-modifying anti-rheumatic drugs (DMARDs) [10]. Several biological DMARDs, including TNF- $\alpha$ blockers and IL-6 receptor (IL-6R) inhibitors, have been used to treat RA [11]. However, most of these drugs act slowly or produce severe adverse reactions after long-term application. Many RA patients do not respond favorably to methotrexate, and not all RA patients respond to biological DMARDs in terms of retardation of joint destruction $[12,13]$. Therefore, drugs with good curative effect and low adverse reactions are needed for RA patient.

Traditional Chinese medicine has a significant effect on treating long-term chronic diseases such as RA [14]. It has been reported that the combination of scolopendra and scorpion with herbal medicine is effective in the clinical treatment of RA [15]. Soufeng sanjie formula (SF) is thus a prescription, which is composed of scolopendra (dried body of Scolopendra subspinipes mutilans L. Koch), scorpion (dried body of Buthus martensii Karsch), astragali radix (dried root of Astragalus membranaceus (Fisch.) Bge), and black soybean seed coats (seed coats of Glycine max (L.) Merr). All four of its components have been extensively studied, and several studies have shown that some of the components in $\mathrm{SF}$ can treat RA. For example, a mixture of scolopendra and scorpion powder can attenuate inflammation and articular damage by normalizing $\mathrm{T}$ lymphocyte subsets and the balance of Th1/Th2 cytokines [16]. Astragalus alleviated arthritis in rats by regulating the OPG/ RANKL/NF- $k B$ pathway [17]. Black soybean seed coats alleviated arthritis in CIA mice by suppressing nuclear factor kappa-B (NF-kB) signaling [18]. Although SF is a traditional prescription for the treatment of RA and show beneficial clinical effects, only limited studies have been conducted on the pharmacological research of SF to date and the mechanism of SF in treating RA is still unclear $[15,19]$. In the present study, we investigated the therapeutic potency of SF in a CIA mouse model and explored the possible mechanism of SF in RA treatment via in vivo and in vitro experiments.

\section{Methods \\ Reagents}

Processed scorpion (Batch No. 20100108), scolopendra (Batch No. 20200301), astragali radix (Batch No. 2010012), black soybean seed coats (Batch No. 200414), and methotrexate (MTX) were purchased from Jiangsu Integrated Traditional Chinese and Western Medicine Hospital (Nanjing, Jiangsu, China). Calycosin and protocatechuic acid were purchased from Yuanye BioTechnology (Shanghai, China). Bovine type II collagen and Freund's adjuvant were purchased from Chondrex (Redmond, WA, USA). An enzyme-linked immunosorbent assay (ELISA) kit for anti-bovine collagen II-specific antibodies was purchased from Chondrex (Redmond, WA, USA). Cell counting kit-8 was purchased from MCE (NJ, USA). Antibodies against IL$17 \mathrm{~A}$ and retinoic acid receptor-related orphan nuclear receptor $\gamma \mathrm{t}(\mathrm{ROR} \gamma \mathrm{t})$ were purchased from Abcam (Cambridge, UK). Antibodies against STAT3 and phosphorylated STAT3 (pSTAT3, Tyr705) were purchased from Cell Signaling (Boston, USA). Antibodies against IL-6, TNF- $\alpha$, and interleukin-10 (IL-10) were purchased from Servicebio (Wuhan, China). ELISA kits for TNF- $\alpha$, IL-6, IL-17A, and IL-10 were purchased from R\&D Systems (Minneapolis, MN, USA). Antibodies against anti-mouse CD3, anti-CD4, anti-CD25, anti-Foxp3, and anti-IL-17A were purchased from BD Biosciences (Franklin Lakes, NJ, USA). Anti-mouse CD4 magnetic particles were purchased from BD Biosciences (Franklin Lakes, NJ, USA). The permeabilization solution kit was purchased from BD Biosciences (Franklin Lakes, NJ, USA). The cell stimulation cocktail was purchased from Invitrogen (Carlsbad, CA, USA). The HiScript Reverse Transcription system was purchased from Vazyme Biotech (Nanjing, Jiangsu, China). TRIzol reagent was purchased from Invitrogen (Carlsbad, CA, USA). 


\section{Preparation of SF}

SF was provided by the pharmacy of Jiangsu Province Hospital on Integration of Chinese and Western Medicine (Jiangsu, China) and was composed of scolopendra, scorpion, astragali radix and black soybean seed coats. The daily dose of SF crude drug administered by humans in the clinic was $0.85 \mathrm{~g} / \mathrm{kg}$. The processed scorpion and scolopendra were crushed through an 80-mesh sieve to form a fine powder, which was further crushed into ultrafine powder using a cryogenic ball mill. Astragali radix and black soybean seed coats were decocted twice with $600 \mathrm{~mL}$ of water at $100{ }^{\circ} \mathrm{C}$ for $1 \mathrm{~h}$ to obtain an aqueous extract, based on a previously reported procedure [20]. The aqueous extract was freeze-dried at $-80^{\circ} \mathrm{C}$ for $72 \mathrm{~h}$ to obtain a freeze-dried powder. The freeze-dried SF powder was dissolved in double distilled water and used in the in vivo and in vitro experiments.

\section{HPLC-Q-TOF-MS analysis and quality control of SF} HPLC-Q-TOF-MS analysis was performed to identify the main compounds in SF $(50 \mathrm{mg} / \mathrm{mL})$. Chromatographic separation was performed using an Agilent $\mathrm{C} 18$ column $(3.0 \mathrm{~mm} \times 100 \mathrm{~mm}, 2.7 \mu \mathrm{m}$; Agilent Technologies, Santa Clara, CA, USA) at $40^{\circ} \mathrm{C}$. The mobile phase consisted of water containing $0.1 \%$ phosphoric acid (A) and acetonitrile (B). The gradient program was set as follows: $0-0.01 \mathrm{~min}, 5 \% \mathrm{~B} ; 0.01-25 \mathrm{~min}, 5-95 \% \mathrm{~B}$; 25-27 min, 5\% B; $27-30$ min, $5 \%$ B. The mobile phase flow rate was $0.3 \mathrm{~mL} / \mathrm{min}$, and the sample injection volume was $2 \mu \mathrm{L}$. Electrospray ionization (ESI) with positive ion modes was used for mass detection. The source parameters were set as follows: spray voltage, $4.5 \mathrm{kV}$; gas temperature, $550{ }^{\circ} \mathrm{C}$; pressure of nebulizer gas, 55 psi; full scan range, $\mathrm{m} / \mathrm{z}$ 50-1000.

The main ingredient in SF $(50 \mathrm{mg} / \mathrm{mL})$ was confirmed using an Agilent 1260 liquid chromatography system. Methanol (80\%) was used as the extraction solvent for the ultrasonic treatment of SF. The SF was separated on an X-Bridge C18 column ( $250 \mathrm{~mm} \times 4.6 \mathrm{~mm}, 5 \mu \mathrm{m})$ maintained at $25^{\circ} \mathrm{C}$. The mobile phase consisted of acetonitrile (A) and $0.1 \%$ phosphate buffer (B) in a gradient elution: $0-10 \mathrm{~min}, 5 \% \mathrm{~A} ; 10-11 \mathrm{~min}, 5-15 \% \mathrm{~A} ; 11-20$ min, $15-18 \%$ A; $20-30 \mathrm{~min}, 18-20 \%$ A; $31-40 \mathrm{~min}$, 20-30\% A; 31-40 min, 30-37\% A; 40-46 min, 37-90\% A. The flow rate was $1 \mathrm{~mL} / \mathrm{min}$, the injection volume was $10 \mu \mathrm{L}$, and detection was set at $260 \mathrm{~nm}$. Chromatographic data were acquired and analyzed using the Empower software (Agilent). The peaks of protocatechuic acid and calycosin in SF were identified by comparing peak retention times with those of the reference compounds.

\section{Animals}

Six-to-eight-week-old female C57BL/6 and DBA/1J mice were purchased from Changzhou Cavens Experimental Animal Co., Ltd. (Jiangsu, China) and maintained under specific pathogen-free conditions at the Animal Center of Jiangsu Province Academy of Traditional Chinese Medicine. All mice raised in circumstances that alternated between $12 \mathrm{~h}$ of light and $12 \mathrm{~h}$ of darkness at the temperature of $20-25{ }^{\circ} \mathrm{C}$ and relative humidity of $50-70 \%$. All animal experimental procedures were performed in accordance with the national and international guidelines and regulations, and were approved by the Animal Ethics Committee of Jiangsu Province Academy of Traditional Chinese Medicine.

\section{CIA induction and drug administration}

CIA mice were immunized twice using bovine type II collagen. In the first immunization, bovine collagen II and Freund's complete adjuvant were mixed and administered as an intradermal injection at the base of the tail in each mouse (100 $\mu \mathrm{g} /$ mouse). On day 21 , a booster injection was given using bovine collagen II and Freund's incomplete adjuvant. DBA/1J female mice were randomly divided into five groups: normal group (Normal, $\mathrm{n}=5$ ), CIA vehicle group (CIA vehicle, $\mathrm{n}=5$ ), methotrexate group (MTX, $n=5$ ), SF low-dose group (SF-L, $183 \mathrm{mg} / \mathrm{kg}, \mathrm{n}=5$ ), and SF high-dose group (SF-H, 550 $\mathrm{mg} / \mathrm{kg}, \mathrm{n}=5$ ). The doses of SF and MTX used in this study were determined from the recommended dosages for humans. Though the doses of SF low $(183 \mathrm{mg} / \mathrm{kg})$ and SF high $(550 \mathrm{mg} / \mathrm{kg})$ were calculated based on a person's daily administration of 1 or $3 \mathrm{~g}$ of scorpion and scolopendra, both SF low and SF high dose treated mice were also administered of $0.99 \mathrm{~g} / \mathrm{kg}$ black soybean seed coats and $0.66 \mathrm{~g} / \mathrm{kg}$ astragali radix based on a person's daily dose (30 g for black soybean seed coats and $20 \mathrm{~g}$ for astragali radix). Oral administration of SF (183 or $550 \mathrm{mg} / \mathrm{kg} /$ day) began 28 days after the first immunization, and MTX was administered at a dose of $920 \mathrm{mg} / \mathrm{kg}$ twice a week. Mice in the normal and vehicle groups were administered an equal volume of deionized water at the same time points.

\section{Evaluation of arthritis}

The incidence of arthritis was evaluated every 3-4 days following immunization. The severity of arthritis was assessed on a scale of $0-4$, based on the following previously described criteria [21]: $0=$ no evidence of erythema or swelling; $1=$ erythema and mild swelling extending to the tarsals or ankle joint; $2=$ erythema and mild swelling extending from the ankle to the tarsals; $3=$ erythema and moderate swelling extending from the ankle to metatarsal joints; $4=$ erythema and severe swelling encompassing 
the ankle, foot, and digits, or ankylosis of the limb. The arthritis score for each mouse was expressed as the sum of the scores of all four limbs. The highest arthritis score that a mouse could have was 16 . Hind paw swelling was measured using a paw volume meter (Woodland Hills, CA, USA).

\section{Histological evaluation}

The mice were sacrificed after 30 days of SF treatment and the hind limbs (including paws and ankles) were collected. The hind limbs were fixed in $4 \%$ paraformaldehyde solution, which was then decalcified with $10 \%$ EDTA for 1 month. After that, the hind limbs were paraffin-embedded, and tissues sectioned and stained with hematoxylin and eosin (H\&E), and Safranin O. The degree of histopathological damage was evaluated based on previously described criteria [22].

\section{Measurement of cytokine and bovine collagen-specific IgG levels}

Blood was collected from each mouse on day 30 of treatment and clotted at $25{ }^{\circ} \mathrm{C}$ for $1 \mathrm{~h}$. Blood was centrifuged at $4000 \mathrm{rpm}$ for $15 \mathrm{~min}$ to obtain serum, which was then stored at $-80{ }^{\circ} \mathrm{C}$ until use. The levels of cytokines and bovine collagen-specific IgG were measured using ELISA kits according to the manufacturers' instructions.

\section{Immunohistochemistry}

The hind limb tissue sections were incubated with antiIL-6, anti-TNF- $\alpha$, anti-IL-10, and anti-IL-17A antibodies. The spleen tissue sections were incubated with ROR $\gamma$ t, STAT3, and pSTAT3 (Tyr705) antibodies, respectively. After incubation with HRP-conjugated goat anti-rabbit and anti-mouse IgG antibody, the expression of IL-6, TNF- $\alpha$, IL-10, IL-17A, ROR $\gamma \mathrm{t}$, STAT3, and pSTAT3 (Tyr705) were visualized using a DAB kit (Servicebio, Wuhan, China). The quantitative analysis of IL-6, TNF$\alpha$, IL-10, IL-17A, ROR $\gamma$ t, STAT3, and pSTAT3 (Tyr705) were performed using Image J $1.37 \mathrm{v}$. The results were expressed as the mean region of interest, and the average optical density was used for statistical analysis.

\section{T-cell isolation and cell viability assay}

$\mathrm{CD}^{+} \mathrm{T}$ cells were isolated from the splenocytes of 6-to8-week-old female C57BL/6 mice using anti-mouse CD4 magnetic particles and an IMag Cell Separation Magnet (BD Biosciences, Franklin Lakes, NJ, USA). To evaluate the effect of SF on the viability of $C D 4^{+} \mathrm{T}$ cells, the cells were treated with different concentrations of SF (0.1-1 $\mathrm{mg} / \mathrm{mL}$ ) for $72 \mathrm{~h}$, and cell viability was detected with a cell counting kit-8.

\section{In vitro Th17 cell differentiation}

The polarization of Th17 cells was performed as previously described [23], CD4 ${ }^{+} \mathrm{T}$ cells were stimulated with plate-bound anti-CD3 $(1 \mu \mathrm{g} / \mathrm{mL})$, anti-CD28 $(1 \mu \mathrm{g} / \mathrm{mL})$, anti-interleukin-4 $(2 \mu \mathrm{g} / \mathrm{mL})$, anti-interferon- $\gamma$ (IFN- $\gamma$, $2 \mu \mathrm{g} / \mathrm{mL}$ ), transforming growth factor- $\beta$ (TGF- $\beta, 2 \mathrm{ng} /$ $\mathrm{mL}$ ), IL-6 (30 ng/mL), interleukin-23 (IL-23, $20 \mathrm{ng} / \mathrm{mL}$ ), and interleukin- $1 \beta$ (IL-1 $\beta, 10 \mathrm{ng} / \mathrm{mL})$ for $72 \mathrm{~h}$. After 3 days, the cells were re-stimulated with a cell stimulation cocktail and then stained with anti-mouse CD4 and antiIL-17A antibodies. The level of IL-17A in the cell supernatant was detected using an ELISA kit.

\section{Flow cytometry}

After oral administration of SF for 30 days, all mice were sacrificed, and the spleen and lymph nodes extracted, mashed and washed with phosphate-buffered saline (PBS). For intracellular IL-17A and Foxp3 staining, the splenocytes and lymph node cells were stimulated with a leukocyte activation cocktail for $5 \mathrm{~h}$. Next, cells were stained with surface FITC-conjugated anti-CD4 antibody or stained with FITC-conjugated anti-CD4 and APCconjugated anti-CD25 antibodies. After fixation and permeabilization, cells were stained with PE-conjugated anti-Foxp3 or PE-conjugated anti-IL-17A antibodies. Finally, the cells were analyzed via flow cytometry (BD Biosciences, Franklin Lakes, NJ, USA). Flow Jo v10 was used to further analyze the levels of Treg and Th17 cells.

\section{Western blot}

$\mathrm{CD}^{+} \mathrm{T}$ cells were cultured for 3 days with or without $\mathrm{SF}(0.1,0.5$, and $1 \mathrm{mg} / \mathrm{mL})$ under Th17-polarizing conditions. Then, total cellular protein was extracted. Protein samples were separated using $10 \%$ sodium dodecyl sulfate-polyacrylamide gel electrophoresis and transferred to a polyvinylidene fluoride membrane (Merck, Darmstadt, Germany). The membrane was preincubated with $5 \%$ BSA in Tris buffered saline (TBS) for $2 \mathrm{~h}$ at room temperature (Sigma, Saint Louis, USA). Diluted STAT-3, pSTAT-3, and GAPDH antibodies (all from Cell Signaling Technology) by $1: 1000$, and the samples were incubated overnight at $4{ }^{\circ} \mathrm{C}$. After incubation with HRPconjugated goat anti-rabbit and anti-mouse IgG antibody, the samples were washed with TBST, and the bands were detected by the Odyssey laser imager (LI-COR, Nebraska, USA). Data were analyzed with Image J 1.37v.

\section{RNA extraction and real-time qPCR}

$\mathrm{CD}^{+} \mathrm{T}$ cells were cultured for 3 days with or without $\mathrm{SF}(0.1,0.5$, and $1 \mathrm{mg} / \mathrm{mL})$ under Th17-polarizing conditions. Total RNA was extracted from $\mathrm{CD} 4^{+} \mathrm{T}$ cells using TRIzol reagent according to the manufacturer's protocol. cDNA was synthesized using the HiScript Reverse 
Transcription system. A 7500 real-time PCR system (Applied Biosystems, Waltham, MA, USA) was used for PCR amplification. All reactions were performed using the ChamQ Universal SYBR qPCR Master Green kit (Vazyme Biotech, Nanjing, China). The $2^{-\Delta \Delta C t}$ method was used for data analysis. The primer sequences used are listed in Table 1.

\section{Statistical analysis}

GraphPad Prism (GraphPad Software version 7.0, San Diego, CA, USA) was used for statistical analysis. Oneway ANOVA and two-way ANOVA with Dunnett's posthoc multiple comparison tests were used to determine statistical significance. Statistical significance was established at $\mathrm{p}<0.05$.

\section{Results}

Identification of chemical compounds in SF by HPLC-Q-TOF-MS and quality control of SF

In the HPLC-Q-TOF-MS experiment, 13 compounds were detected in the SF, as shown in Fig. 1a and Table 2. The 13 compounds were tentatively characterized based on their formula and retention times. According to the Chinese Pharmacopoeia, protocatechuic acid and calycosin were used as references to verify the composition of SF. The representative HPLC chromatograms of standards and SF are shown in Fig. 1b, c. The content of protocatechuic acid and calycosin in SF were analyzed and generated regression equations using the peak area and concentrations. The content of protocatechuic acid in SF was $0.553 \mathrm{mg} / \mathrm{g}$. The content of calycosin in SF was 0.291 $\mathrm{mg} / \mathrm{g}$.

\section{SF suppressed the development of arthritis in CIA mice} DBA/1J mice were immunized with bovine collagen II twice, and SF was administered orally every day, starting 28 days after the first immunization (Fig. 2a). Mice began to show symptoms of arthritis 28 days following the first immunization. As shown in Fig. 2b, the incidence of arthritis reached $100 \% 38,42,44$, and 45 days after immunization in the CIA vehicle group, the MTX group, the SF low-dose group, and the SF high-dose group, respectively. Arthritis scores were assessed and swelling of the hind paw was measured after the booster immunization. Compared with mice in the CIA vehicle group, the arthritis scores of mice in the SF low-dose and SF high-dose groups were significantly reduced from the days 37 to 58 following the first immunization (Fig. 2c). And the arthritis scores of mice in the MTX group was also significantly reduced from the days 34 to 51 . Moreover, compared with mice in the CIA vehicle group, the hind paw swelling of mice in the SF (low-dose and highdose) and MTX groups decreased significantly after day 37 of immunization (Fig. 2d). After administration of SF for 30 days, the hind paw of mice in the CIA vehicle group were severely swollen and deformed, whereas no significant deformation was found among the SF (lowdose and high-dose) and MTX groups (Fig. 2e). Additionally, the body weights of mice in the SF low-dose and SF high-dose groups on days 51, 55 and 58 after immunization were significantly higher than those of the CIA vehicle group mice (Fig. 2f).

\section{SF reduced ankle joint bone destruction and serum levels of CII specific IgG}

Assessment of joint pathology and cartilage destruction by $H \& E$ and Safranin $O$ staining showed that the hind paw joints of CIA mice treated with SF exhibited a significant reduction in cartilage loss and joint destruction compared with the CIA vehicle mice (Fig. 3a). The joint histopathological and cartilage scores of mice in the SF low-dose and SF high-dose groups were also significantly lower than those in the CIA vehicle group (Fig. 3b). Moreover, the levels of bovine collagen II-specific IgG and IgG2a in the sera of mice in the SF low-dose and SF high-dose groups were also significantly lower than those in the CIA vehicle group (Fig. 3c). However, the levels of IgG2b in the sera of mice in the SF low-dose group were lower than those in the CIA vehicle group and the levels of IgG2a in the sera of mice in the MTX group were lower than those in the CIA vehicle group (Fig. 3c).

\section{SF decreased the levels of IL-6, TNF- $a$, and IL-17A, and increased the level of IL-10 both in the serum and joints of $\mathrm{CIA}$ mice}

Next, we measured the inflammatory cytokines associated with RA. Compared with the CIA vehicle group, the sera levels of proinflammatory cytokines TNF- $\alpha$,

Table 1 Primers used for real-time qPCR in the present study

\begin{tabular}{|c|c|c|}
\hline Gene & Forward & Reverse \\
\hline Mouse RORyt & 5'-GACCCACACCTCACAAATTGA-3' & 5'-AGTAGGCCACATTACACTGCT-3' \\
\hline Mouse IL-17A & 5'-TTTAACTCCCTTGGCGCAAAA-3' & 5'-CTTTCCCTCCGCATTGACAC-3' \\
\hline Mouse IRF4 & 5'-TCCGACAGTGGTTGATCGAC-3' & 5'-CCTCACGATTGTAGTCCTGCTT-3' \\
\hline Mouse GAPDH & 5'-TGTGGATGGCCCCTCTGGAA-3' & 5'-TGACCTTGCCCACAGCCTTG-3' \\
\hline
\end{tabular}



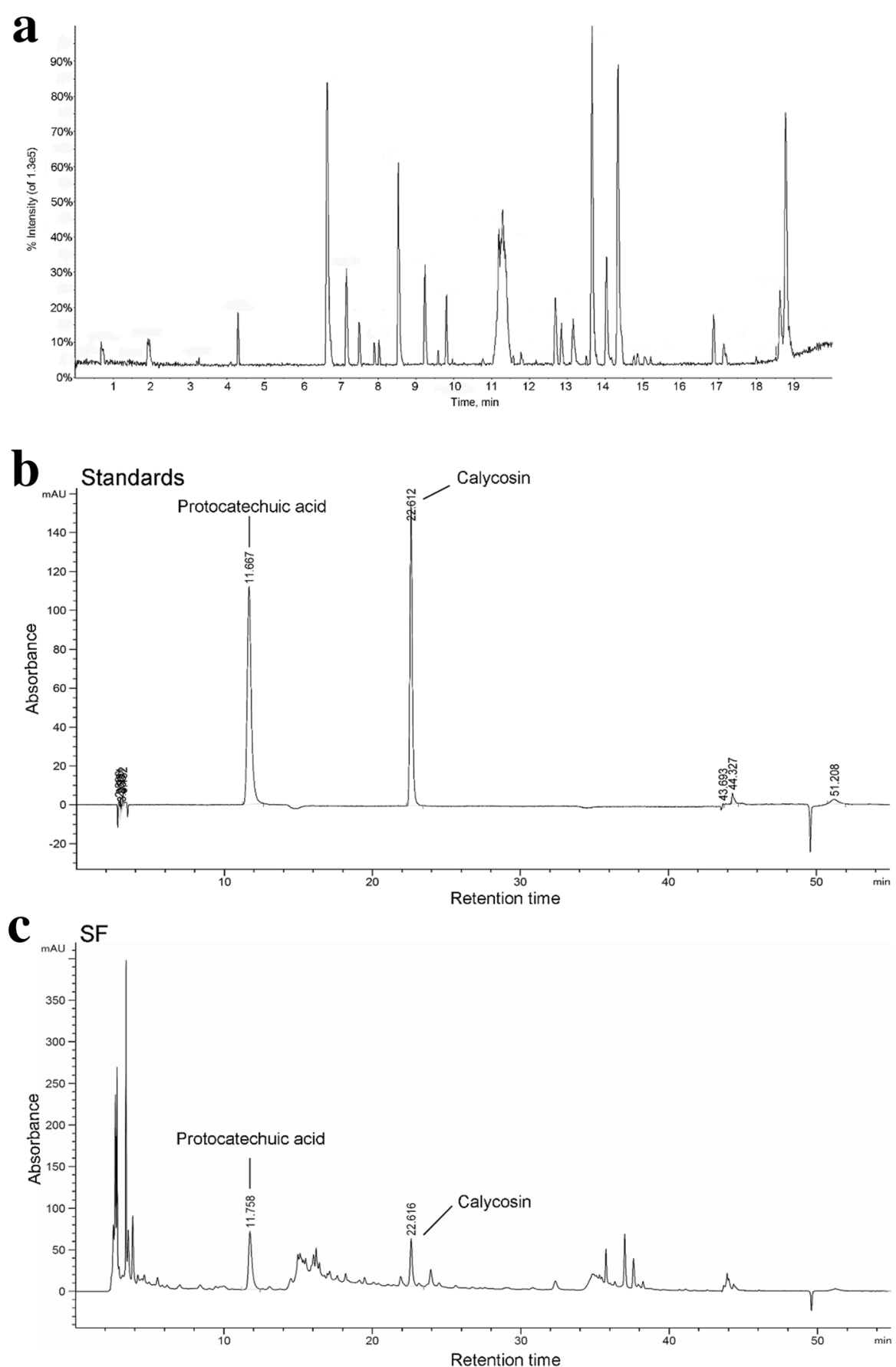

Fig. 1 Identification of chemical compounds in SF by HPLC-Q-TOF-MS and quality control of SF. a Representative base peak intensity chromatogram of SF based on HPLC-Q-TOF-MS in positive mode. $\mathbf{b}$ HPLC chromatograms of calycosin and protocatechuic acid at $260 \mathrm{~nm}$. $\mathbf{c}$ HPLC chromatogram of SF at $260 \mathrm{~nm}$

IL-6, and IL-17A were significantly decreased in the SF low-dose and SF high-dose groups (Fig. 4a), and the levels of IL-6 and IL-17A were significantly decreased in the MTX group compared to those in the CIA vehicle group (Fig. 4a). Moreover, the levels of IL-10 in the sera of mice in the SF high-dose group were higher than those in the CIA vehicle group (Fig. 4a). In addition, the expression levels of TNF- $\alpha$, IL-6, and IL-17A were significantly downregulated in the ankle joints of the SF (low-dose and high-dose) compared with those in the CIA vehicle group 
Table 2 Characteristics of compounds identified in SF through HPLC-Q-TOF-MS

\begin{tabular}{|c|c|c|c|c|c|}
\hline NO & Rt (min) & Identification & Formula & $\mathrm{m} / \mathrm{z}$ & Error (ppm) \\
\hline 1 & 0.66 & $L(+)$-Arginine & $\mathrm{C}_{6} \mathrm{H}_{14} \mathrm{~N}_{4} \mathrm{O}_{2}$ & $\begin{array}{l}{[\mathrm{M}+\mathrm{H}]^{+}} \\
175.1189\end{array}$ & -0.6 \\
\hline 2 & 0.72 & L-Proline & $\mathrm{C}_{5} \mathrm{H}_{9} \mathrm{NO}_{2}$ & $\begin{array}{l}{[\mathrm{M}+\mathrm{H}]^{+}} \\
116.0706\end{array}$ & -0.5 \\
\hline 3 & 3.22 & $\begin{array}{l}\text { 2-(7,8-dimethyl-2,4-dioxobenzo[g] } \\
\text { pteridin-10-yl) acetaldehyde }\end{array}$ & $\mathrm{C}_{14} \mathrm{H}_{12} \mathrm{~N}_{4} \mathrm{O}_{3}$ & $\begin{array}{l}{[\mathrm{M}+\mathrm{NA}]^{+}} \\
307.0801\end{array}$ & 4.7 \\
\hline 4 & 4.08 & Epicatechin & $\mathrm{C}_{15} \mathrm{H}_{14} \mathrm{O}_{6}$ & $\begin{array}{l}{[\mathrm{M}+\mathrm{H}]^{+}} \\
291.0863\end{array}$ & 2 \\
\hline 5 & 6.71 & L-Leucine & $\mathrm{C}_{6} \mathrm{H}_{13} \mathrm{NO}_{2}$ & $\begin{array}{l}{[\mathrm{M}+\mathrm{COOH}]^{+}} \\
176.0917\end{array}$ & 2 \\
\hline 6 & 8.11 & Calycosin & $\mathrm{C}_{16} \mathrm{H}_{12} \mathrm{O}_{5}$ & $\begin{array}{l}{[\mathrm{M}+\mathrm{H}]^{+}} \\
285.0757\end{array}$ & 0.8 \\
\hline 7 & 8.57 & $\begin{array}{l}\text { Fmoc-L-1,2,3,4-tetrahydro-norharman- } \\
\text { 3-carboxylic acid }\end{array}$ & $\mathrm{C}_{27} \mathrm{H}_{22} \mathrm{~N}_{2} \mathrm{O}_{4}$ & $\begin{array}{l}{[\mathrm{M}+\mathrm{H}]^{+}} \\
439.1652\end{array}$ & -5 \\
\hline 8 & 11.57 & Palmitic acid & $\mathrm{C}_{16} \mathrm{H}_{32} \mathrm{O}_{2}$ & $\begin{array}{l}{\left[\mathrm{M}+\mathrm{NH}_{2}\right]^{+}} \\
272.2584\end{array}$ & 3.1 \\
\hline 9 & 11.83 & Oleic acid & $\mathrm{C}_{18} \mathrm{H}_{34} \mathrm{O}_{2}$ & $\begin{array}{l}{\left[\mathrm{M}+\mathrm{NH}_{2}\right]^{+}} \\
298.2740\end{array}$ & 0.4 \\
\hline 10 & 12.84 & Ethyl 3,4-dihydroxybenzoate & $\mathrm{C}_{9} \mathrm{H}_{10} \mathrm{O}_{4}$ & $\begin{array}{l}{[\mathrm{M}+\mathrm{H}]^{+}} \\
183.0651\end{array}$ & 1.9 \\
\hline 11 & 13.73 & Astragaloside I & $\mathrm{C}_{45} \mathrm{H}_{72} \mathrm{O}_{16}$ & $\begin{array}{l}{[\mathrm{M}+\mathrm{COOH}]} \\
913.4791\end{array}$ & 3.2 \\
\hline 12 & 14.39 & Delphinidin chloride & $\mathrm{C}_{15} \mathrm{H}_{11} \mathrm{ClO}_{7}$ & $\begin{array}{l}{[\mathrm{M}+\mathrm{COOH}]^{+}} \\
383.0164\end{array}$ & 0.8 \\
\hline 13 & 15.39 & a-Linolenic acid & $\mathrm{C}_{18} \mathrm{H}_{32} \mathrm{O}_{2}$ & $\begin{array}{l}{[\mathrm{M}+\mathrm{H}]^{+}} \\
279.2318\end{array}$ & 1.7 \\
\hline
\end{tabular}

(Fig. 4b, c). Meanwhile, the expression level of IL-10 was significantly upregulated in the ankle joints of the SF high group compared with those in the CIA vehicle group (Fig. 4b, c).

\section{SF treatment rebalanced Th17/Treg ratio in the spleen and lymph nodes of CIA mice}

As shown in the above results, the sera and joints levels of TNF- $\alpha$, IL-6, and IL-17A of the SF treatment groups were significantly lower than those in the CIA group, while sera and joints level of IL-10 was significantly increased. We next investigated the effect of SF on the immune balance in CIA mice. After administration of SF for 30 days, we measured the numbers of Treg and Th17 cells in the spleen and lymph nodes of the mice. As shown in Fig. 5, compared to the normal mice, the number of Th17 $\left(\mathrm{CD} 4^{+} \mathrm{IL}-17^{+}\right)$cells was significantly increased in the spleen and lymph nodes of CIA mice, while the number of Treg $\left(\mathrm{CD} 4^{+} \mathrm{CD} 25^{+} \mathrm{Foxp} 3^{+}\right)$cells was significantly decreased in the spleen of CIA mice. Meanwhile, the ratio of Th17/Treg cells in the spleen and lymph nodes of the CIA vehicle group was significantly higher than that in the normal group (Fig. 5c, f). However, compared with mice in the CIA vehicle group, the numbers of Th17 cells and the ratio of Th17/
Treg in the spleen and lymph nodes of the SF (low-dose and high-dose) and MTX groups were significantly reduced (Fig. 5c, f). Note that only the number of Treg cells in the spleen of mice in the SF high-dose group increased significantly and the number of Th17 cells in the lymph nodes of mice in the MTX group decreased significantly (Fig. 5a, e). In addition, we also detected the levels of Th1 and Th2 in the spleen of each group of mice. Although the Th1 cell level of the CIA group was significantly higher than that of the normal group, and the Th1/Th2 ratio of the CIA group was also significantly lower than that of the normal group, there was no significant difference in Th1, Th2 and Th1/Th2 between the SF-L and SF-H groups and the CIA vehicle group (Additional file 1: Fig. 1).

\section{SF decreased the expression levels of RORyt and pSTAT3 in the spleen of $\mathrm{CIA}$ mice}

To investigate the signaling pathway that SF reduced the level of Th17 cells in CIA mice, the expression levels of RORyt, STAT3, and pSTAT3 (Tyr705) in the spleen of each group of mice were measured. As shown in Fig. 6a, $\mathrm{b}$, compared with the normal group, the expression levels of RORyt and pSTAT3 (Tyr705) in the spleen of the 

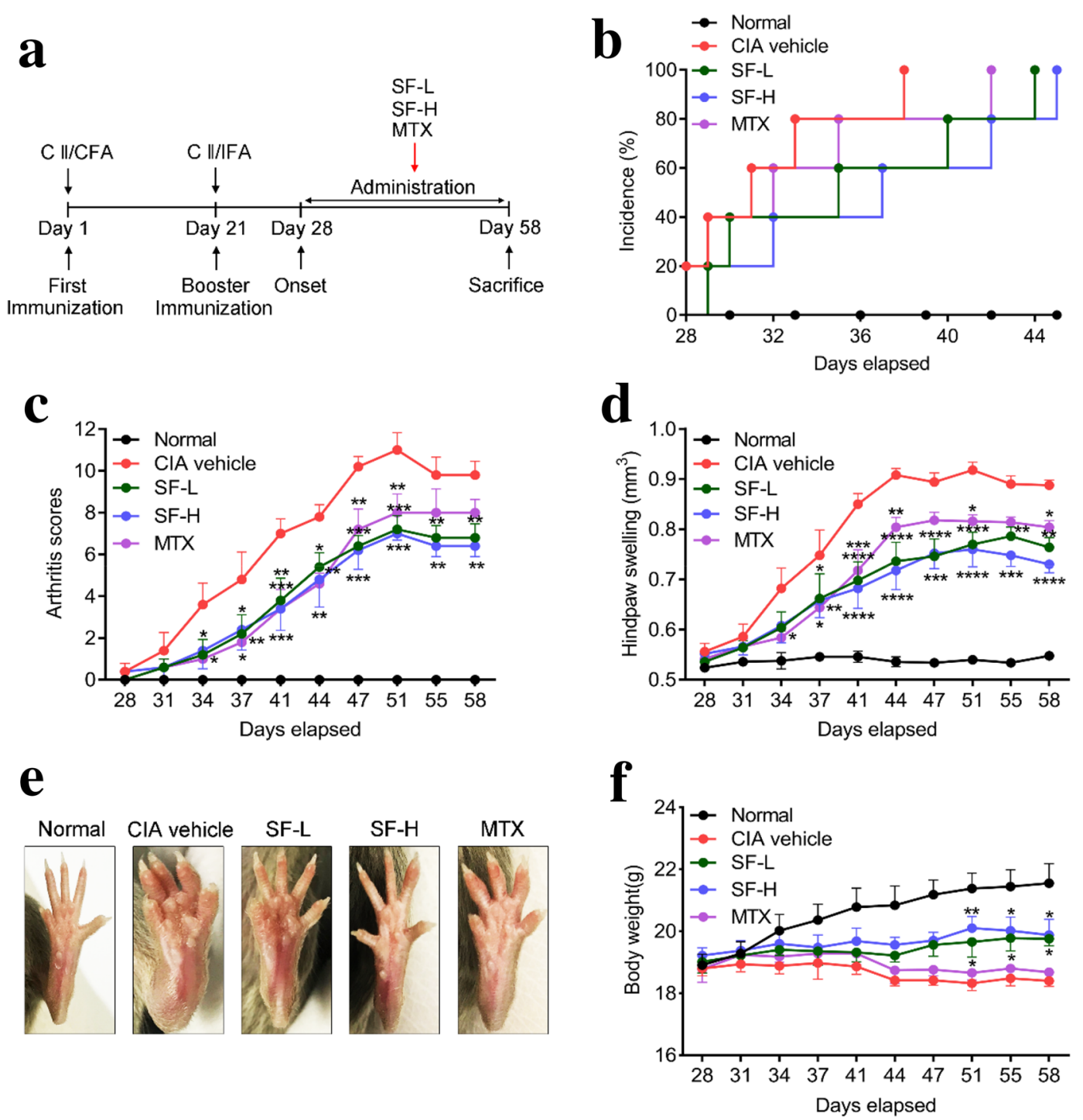

Fig. 2 Effect of SF on onset and clinical symptoms of arthritis in CIA mice. a Flow chart of CIA model induction and treatment options. $\mathbf{b}$ Incidence of arthritis in each group $(n=5)$. c Arthritis scores of mice in each group $(n=5)$. $\mathbf{d}$ Hind paw swelling of mice in each group $(n=5)$. e Representative images of feet in each group after one-month administration $(n=5)$. $\mathbf{f}$ Body weight of mice in each group. Values are presented as means $\pm S E M$. Two-way ANOVA and post hoc Dunnett's test were performed between multiple groups. ${ }^{*} p<0.05,{ }^{* *} p<0.01,{ }^{* * *} p<0.001,{ }^{* * *} p<0.0001$ compared with CIA vehicle group

CIA vehicle group increased significantly. However, compared with the CIA vehicle group, the expression levels of RORyt and pSTAT3 (Tyr705) in the spleen of the SF treatment group and the MTX group were significantly reduced.

\section{SF inhibited Th17 cell differentiation and Th17-related mRNA expression in vitro}

Next, we investigated the effect of SF on Th17 cells using an in vitro model of Th17 cell differentiation. First of all, $\mathrm{CD} 4^{+} \mathrm{T}$ cells were isolated from the splenocytes of
C57BL/6 mice and treated with different concentrations of SF (0.1-1 mg/mL). As shown in Fig. 7a, SF (0.1-1 mg/ $\mathrm{mL}$ ) had no effect on $\mathrm{CD} 4^{+} \mathrm{T}$ cell viability. The $\mathrm{CD} 4^{+} \mathrm{T}$ cells were then incubated under Th17-polarizing conditions in the presence or absence of SF $(0.1-1 \mathrm{mg} / \mathrm{mL})$. SF reduced IL-17A levels in the cell supernatant in a dose-dependent manner (Fig. 7b). Moreover, compared with unpolarized $\mathrm{CD} 4^{+} \mathrm{T}$ cells, the number of Th17 cells increased significantly after polarization, while Th17 cells in the SF treatment group decreased significantly in a dose-dependent manner (Fig. 7c, d). Next, the mRNA 


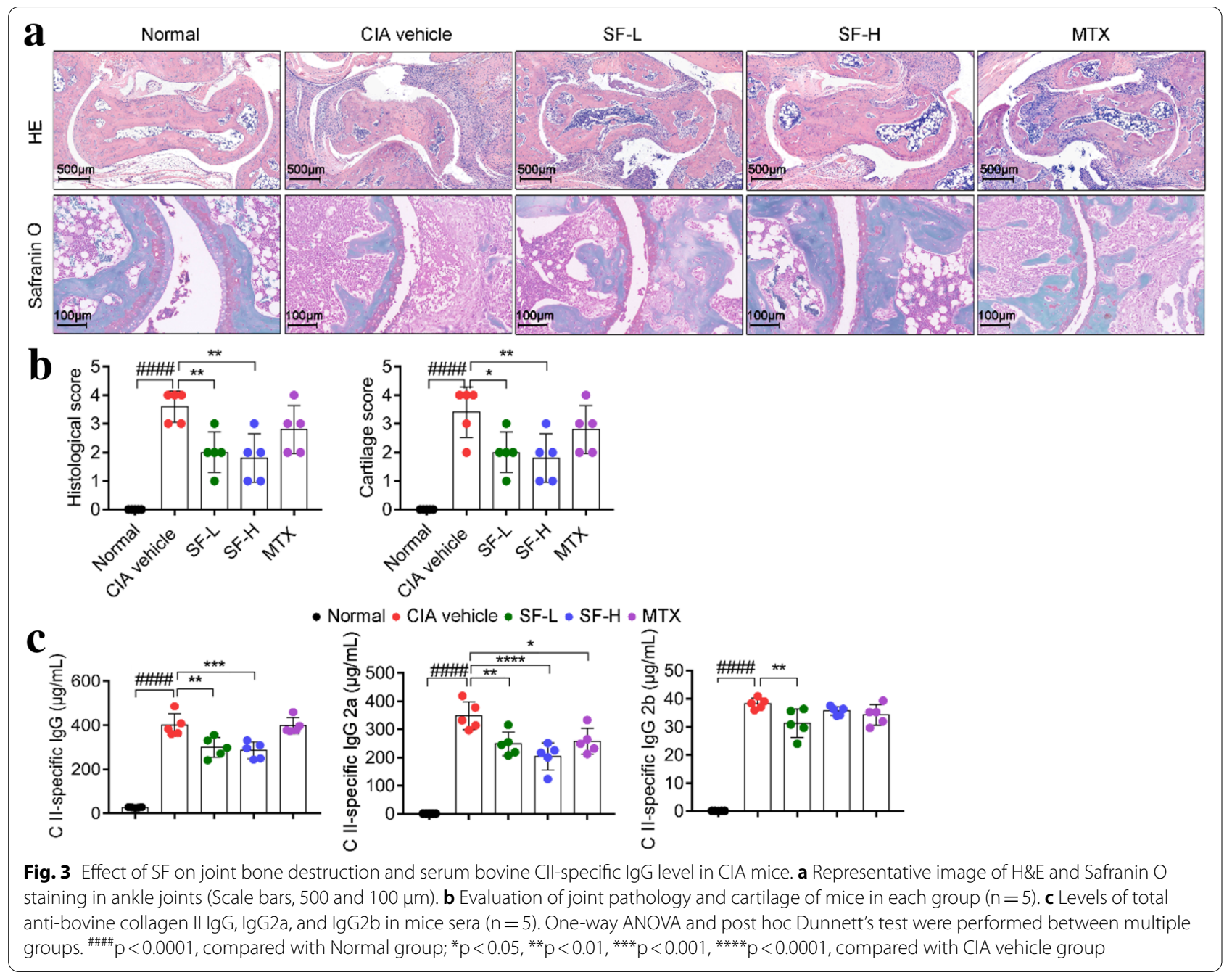

expression of Th17-associated cytokines and Th17-specific transcription cytokine RORyt were analyzed. Compared with unpolarized $\mathrm{CD} 4^{+} \mathrm{T}$ cells, the mRNA levels of IL-17A, ROR $\gamma \mathrm{t}$, and IRF4 in CD4 ${ }^{+} \mathrm{T}$ cells under Th17 polarization conditions increased significantly, while the mRNA levels of IL-17A and RORyt in the SF treatment group decreased significantly in a dose-dependent manner (Fig. 7e). However, only SF $1 \mathrm{mg} / \mathrm{mL}$ significantly reduced the mRNA level of IRF4 (Fig. 7e). To investigate the signaling pathway of SF regulating Th17 cell differentiation in vitro, the expression levels of STAT3 and pSTAT3 (Tyr705) in $\mathrm{CD}^{+}{ }^{+} \mathrm{T}$ cells were evaluated by Western blotting. As shown in Fig. 7f, the level of pSTAT3 (Tyr705) in CD4 ${ }^{+} \mathrm{T}$ cells was decreased by treatment with SF under Th17 polarization conditions.

\section{Discussion}

Previous studies have shown that traditional Chinese medicine is an alternative medicine for treating longterm chronic diseases such as RA [24]. Traditional Chinese medicine, characterized by monarch, minister, adjuvant and assistant, emphasizes the integrated treatment based on multicomponent action instead of the single-component therapy, which is the typical superiority of traditional Chinese medicine prescription. Treatment by the combination formulae has been verified scientifically for treatment on several diseases as an effective complementary or alternative therapy [25]. In the present study, we demonstrated that SF had a significant therapeutic effect in a CIA mouse model, as evidenced by significantly decreased arthritis scores, joint swelling, and cartilage loss in CIA mice treated with SF compared with CIA vehicle mice. This beneficial effect of SF may be through maintaining the balance of Treg/Th17 cells, down-regulating the expression of TNF- $\alpha$, IL-6, IL-17A, 


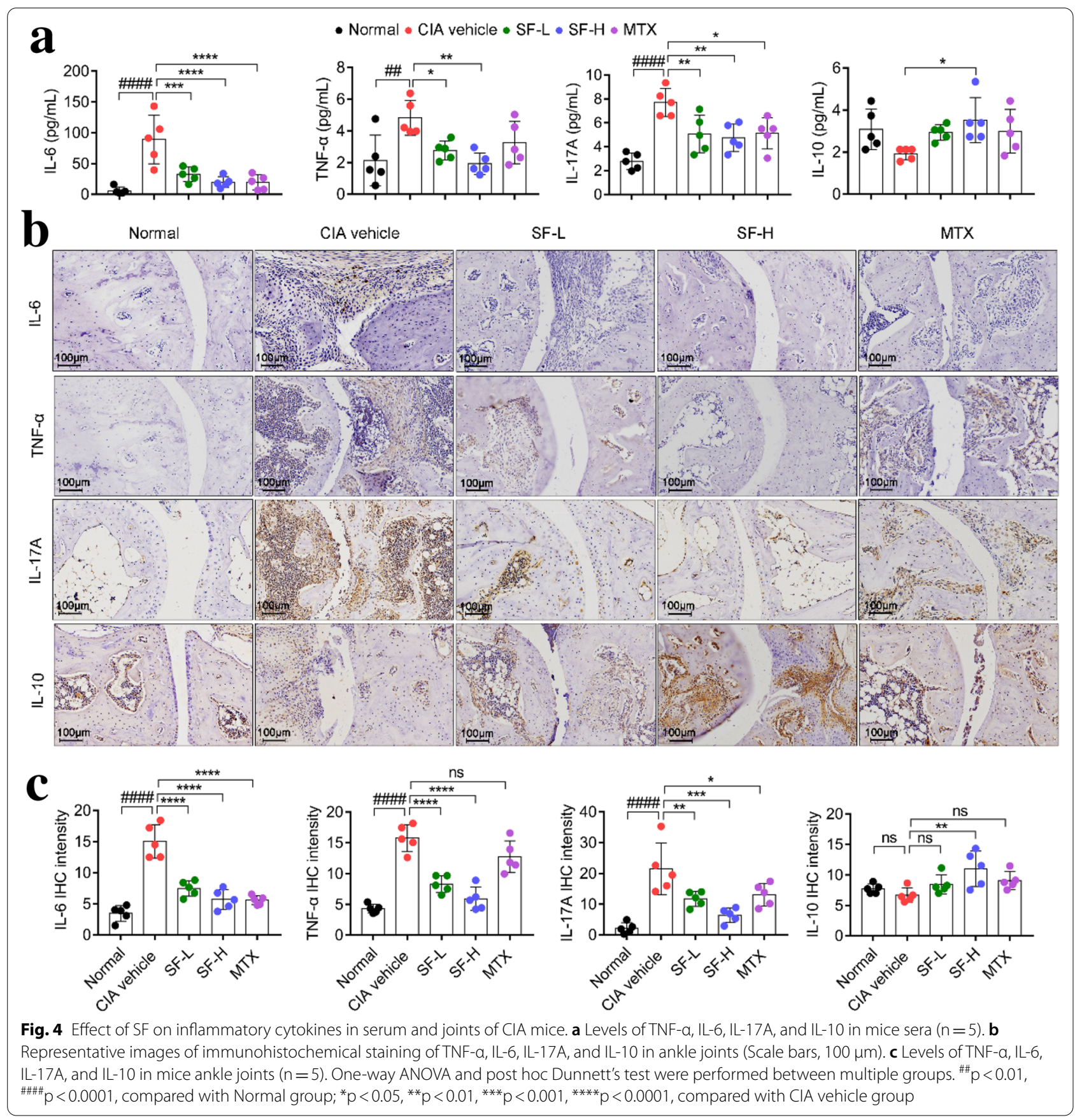

up-regulating IL-10 expression, and inhibiting the formation of IgG antibodies. Although the main chemical components of SF for the treatment of arthritis have not been identified, it has been reported that peptides in scorpion and scolopendra can reduce inflammation and joint damage by regulating $\mathrm{T}$ lymphocytes, and total flavonoids in astragalus can relieve arthritis inflammation in rats, and black soybean coat extract can alleviate joint inflammation in CIA mice by inhibiting Th17 cells [16-18]. The components in SF were complex, and the main components of SF in the treatment of RA need to be further explored.

The pathogenesis of RA is complex, TNF- $\alpha$ and IL- 6 are considered to be central hubs in the synovial cytokine network of RA [26]. These cytokines stimulate osteoclast formation and the subsequent degradation of bone and cartilage, and also potently induce the release of other pro-inflammatory mediators, such as 

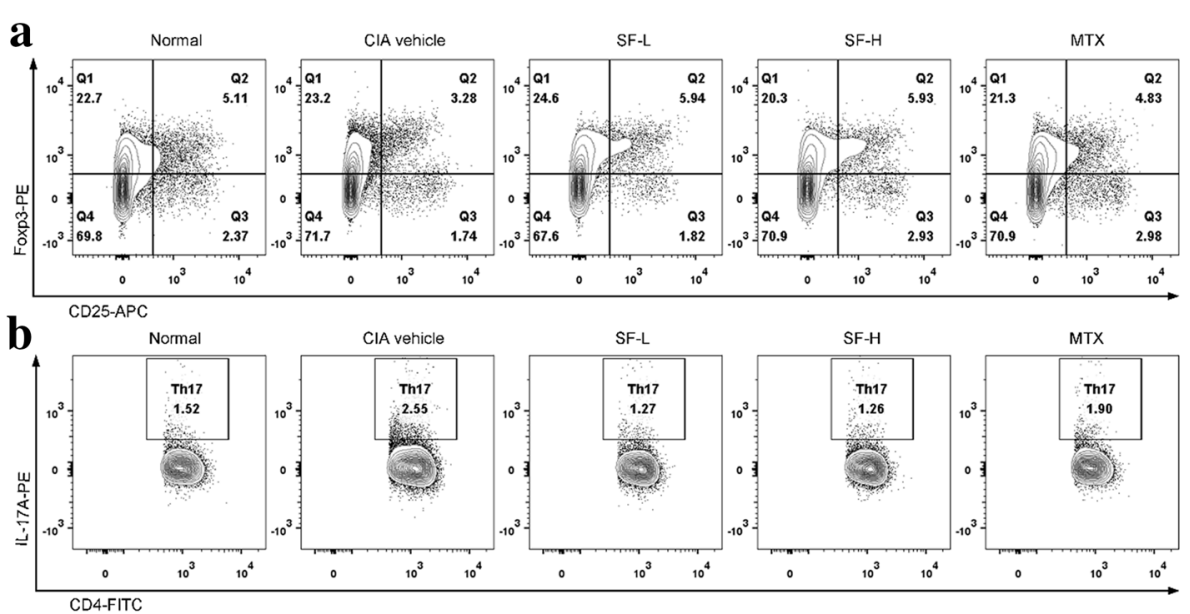

C
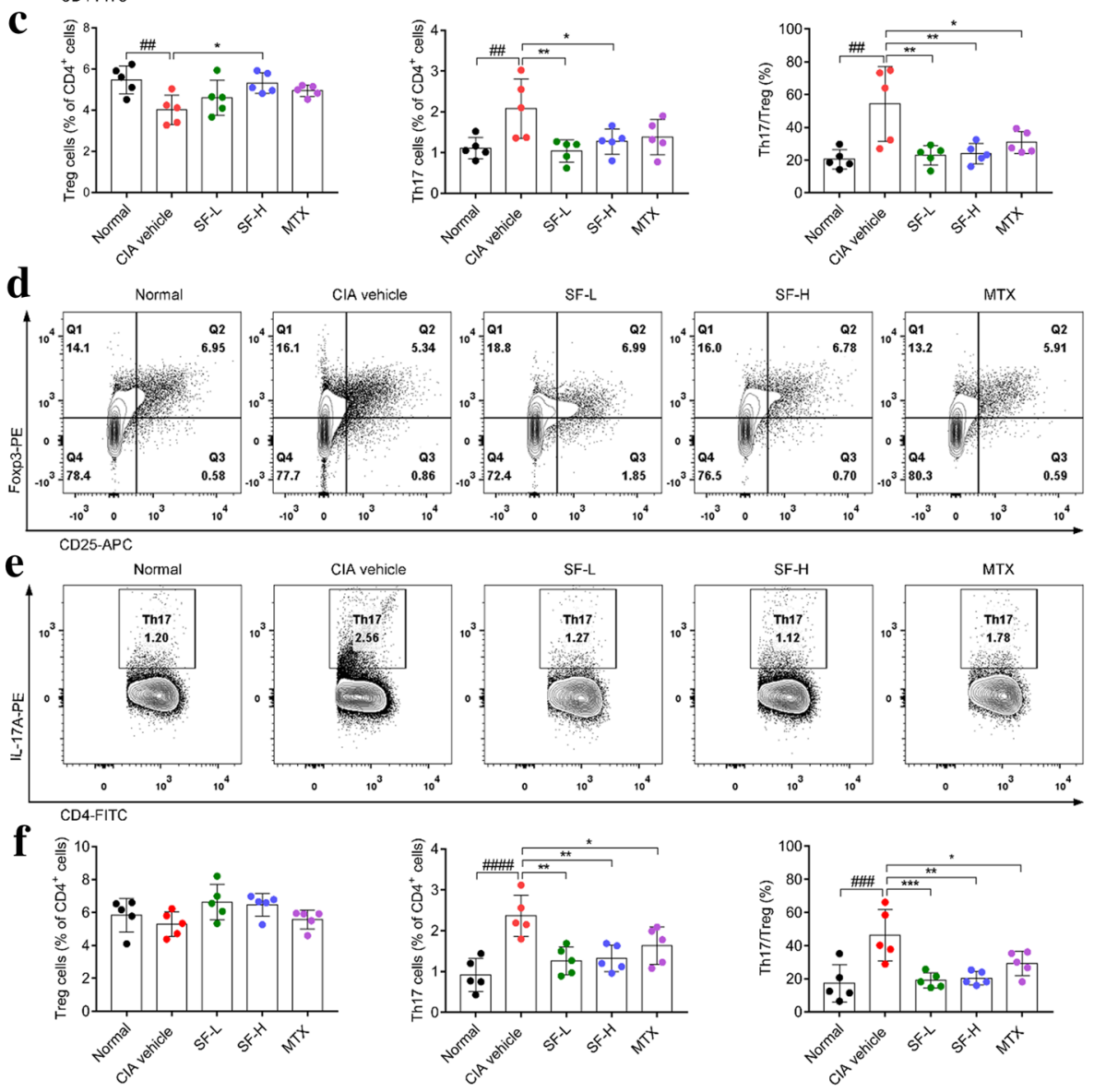

Fig. 5 Effect of SF on Treg and Th17 cells in the spleen and lymph nodes of CIA mice. a Representative image of CD $4^{+} \mathrm{CD} 25^{+} \mathrm{Foxp} 3^{+}$cells in spleen after one-month administration. $\mathbf{b}$ Representative image of $\mathrm{CD} 4^{+} \mathrm{IL}-17 \mathrm{~A}^{+}$cells in spleen after one-month administration. $\mathbf{c}$ Proportion of Treg and Th17 cells and ratio of Treg/Th17 in the spleen of each group of mice $(n=5)$. $\mathbf{d}$ Representative image of $C D 4^{+} C D 25^{+}$Foxp3 ${ }^{+}$cells in lymph nodes after 1-month administration. e Representative image of $\mathrm{CD}^{+}{ }^{+} \mathrm{L}-17 \mathrm{~A}^{+}$cells in lymph nodes after 1-month administration. f Proportion of Treg and Th17 cells and ratio of Treg/Th17 in the lymph nodes of each group of mice $(n=5)$. One-way ANOVA and post hoc Dunnett's test were performed between multiple groups. ${ }^{\# \#} p<0.01,{ }^{\# \# \#} p<0.001,{ }^{\# \# \# \#} p<0.0001$, compared with Normal group; ${ }^{*} p<0.05,{ }^{* *} p<0.01,{ }^{* * *} p<0.001$, compared with CIA vehicle group 

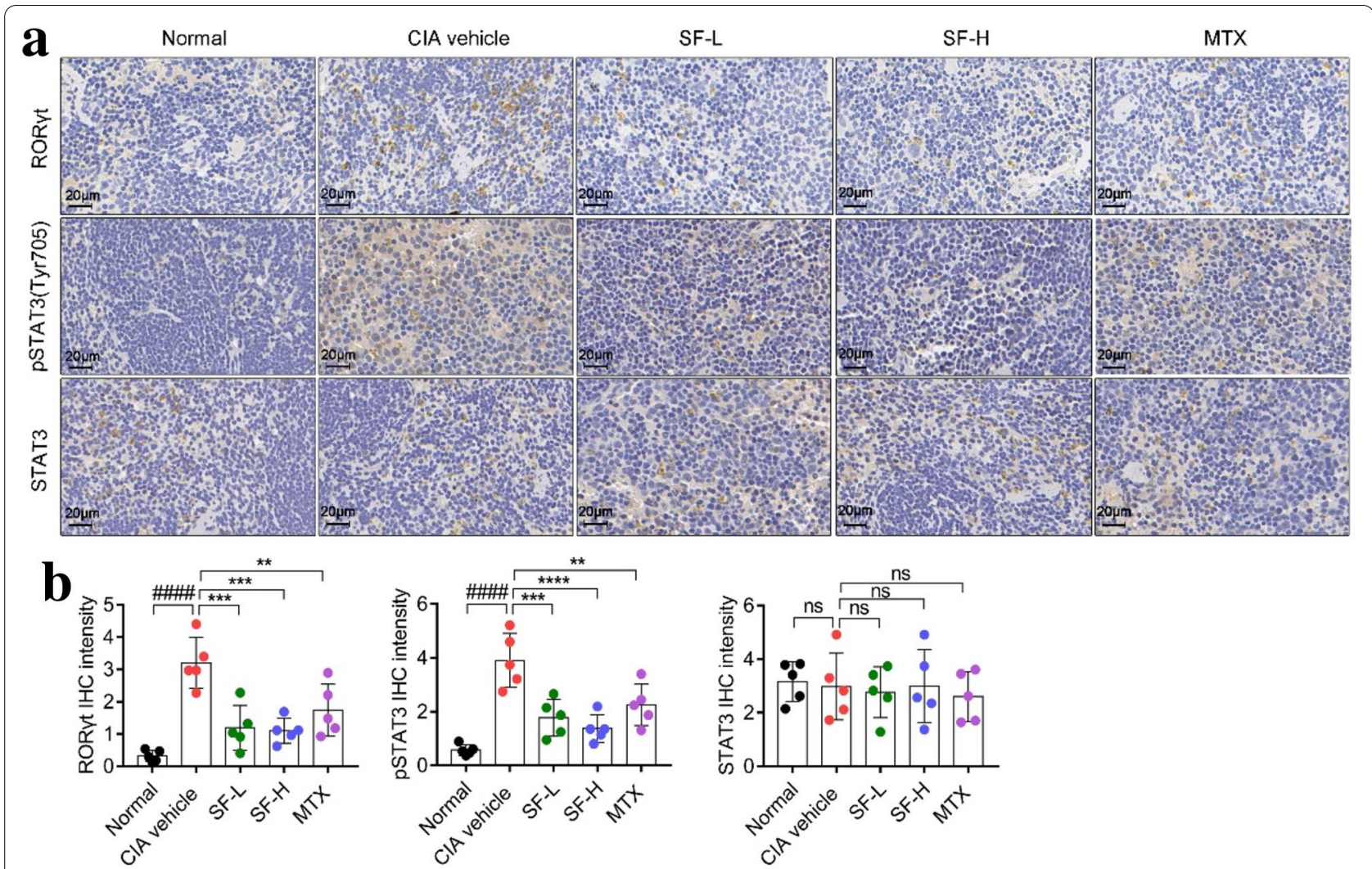

Fig. 6 Effect of SF on the levels of RORYt, STAT3, and PSTAT3 in the spleen of CIA mice. a Representative image of immunohistochemical staining of RORyt, STAT3, and pSTAT3 (Tyr705) in the spleen (Scale bars, $20 \mu \mathrm{m}$ ). b Levels of RORyt, STAT3, and pSTAT3 (Tyr705) in the spleen $(n=5)$. One-way ANOVA and post hoc Dunnett's test were performed between multiple groups. ${ }^{\# \# \#} p<0.0001$, compared with Normal group; ${ }^{* *} p<0.01$, ${ }^{* * *} p<0.001$, ${ }^{* * *} \mathrm{p}<0.0001$, compared with ClA vehicle group

IL-1 and granulocyte-macrophage colony-stimulating factor [27]. In the present study, we found that SF significantly decreased the levels of TNF- $\alpha$, IL-6, and IL-17A in the sera of CIA mice, while sera IL-10 levels were significantly increased. IL-6 mediates Th17 differentiation, and Th17 cells produce inflammatory cytokines, such as IL-17, to augment autoimmune arthritis $[9,28]$. Moreover, anti-inflammatory IL-10 endows Treg cells with the ability to suppress pathogenic Th17 cell responses [29]. We also found that the expression of IL-6, TNF- $\alpha$, and IL-17A in the joints of CIA mice after SF treatment were significantly downregulated, and the expression of IL-10 in the joints of CIA mice after SF treatment was significantly upregulated. Based on these results, we investigated the effect of SF on Treg and Th17 cells in the spleen and lymph nodes of CIA mice.

$\mathrm{CD}^{+}{ }^{+} \mathrm{T}$ helper (Th) cells play central roles in RA regulation [30]. Naive precursor $\mathrm{CD} 4^{+} \mathrm{T}$ cells develop into Th17 cells when exposed to proinflammatory cytokines, including TGF- $\beta$, IL-6, IL-1 $\beta$, and IL-23 [31], and the pro-inflammatory cytokines produced by Th17 cells are involved in the development of RA [32]. In contrast to
Th17 cells, Tregs are indispensable mediators that sustain immune tolerance to self-antigens and help to maintain immune homeostasis [33]. In the present study, although only SF high-dose significantly increased the number of Treg cells in the spleen of CIA mice, SF had a significant inhibitory effect on Th17 cells in the spleen and lymph nodes of CIA mice. The increased of Treg cells in the spleen of CIA mice treated with SF-H may be related to the proliferation and differentiation of naïve CD4 T cells, and further investigation is needed. Furthermore, the ratio of Th17/Treg in the spleen and lymph nodes of CIA mice after SF treatment returned levels similar to that in normal mice. Our findings are consistent with those of other studies showing that maintaining the balance between Th17 and Treg cells is essential for the treatment of RA [6, 8]. Although previous studies have found that a mixture of scolopendra and scorpion powder can attenuate inflammation and articular damage by normalizing $\mathrm{T}$ lymphocyte subsets and the balance of Th1/Th2 cytokines [16], our results showed that SF has no significant effect on Th1 and Th2 cells in the spleen of CIA mice. 

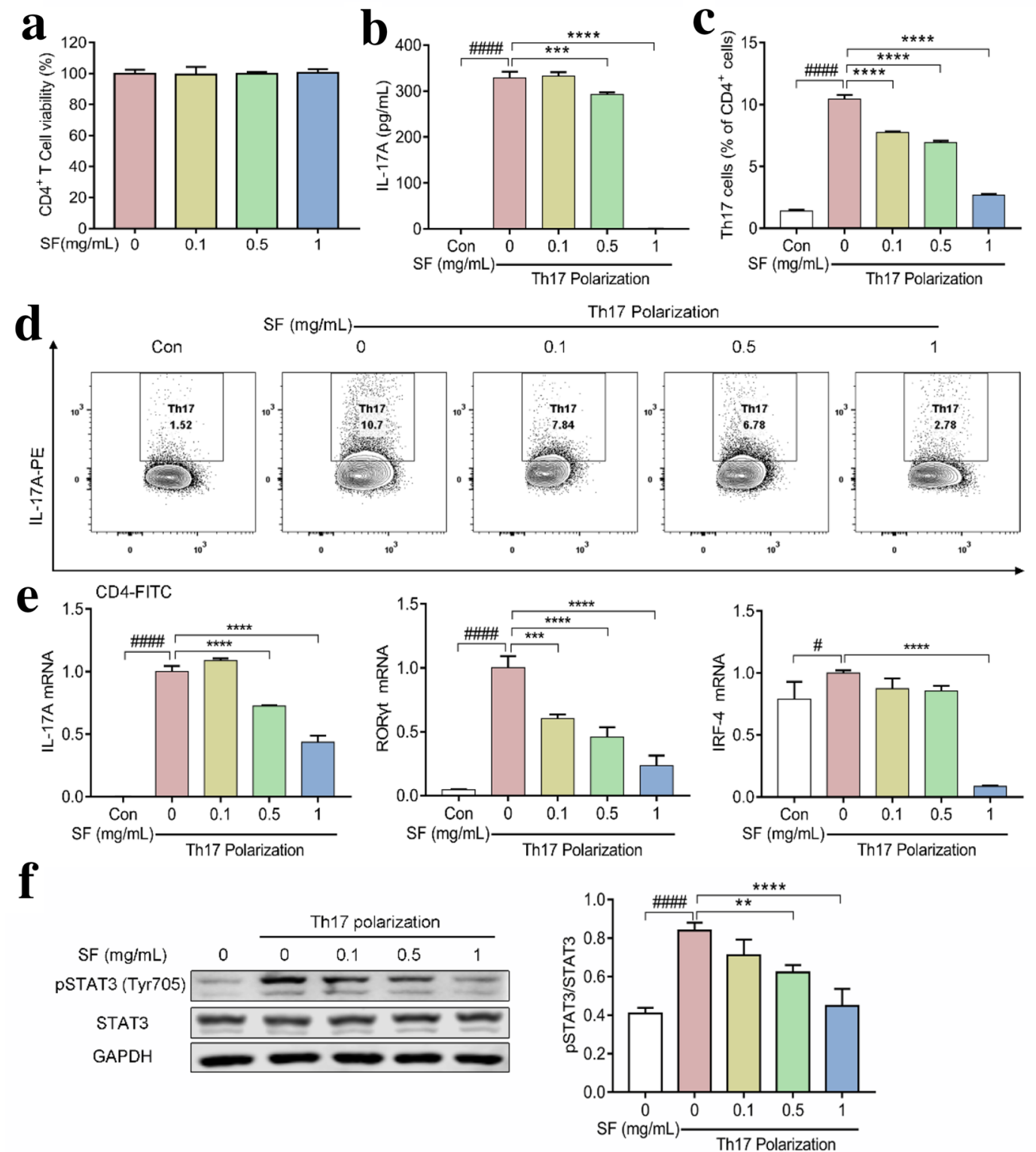

Fig. 7 Effects of SF on Th17 differentiation in vitro. a The effect of SF $(0.1-1 \mathrm{mg} / \mathrm{mL})$ on CD4 ${ }^{+}$cell viability. $\mathbf{b} \mathrm{IL}-17 \mathrm{~A}$ levels in the cell supernatant under Th17-polarizing conditions $(n=3)$. c Proportion of Th17 cells in each group from three independent experiments $(n=3)$. $\mathbf{d}$ Representative

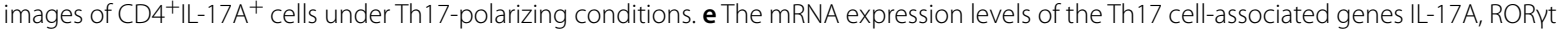
and IRF4 $(n=3)$. f The levels of STAT3 and pSTAT3 (Tyr705) in each group under Th17-polarizing conditions $(n=3)$. One-way ANOVA and post hoc Dunnett's test were performed between multiple groups. ${ }^{\#} p<0.05$, ${ }^{\# \# \#} p<0.0001$, compared with unpolarized group; ${ }^{* *} p<0.01,{ }^{* * *} p<0.001$, ${ }^{* * * *} p<0.0001$, compared with polarized group without treatment

Although IL-17 antibodies show marked clinical efficacy in psoriasis, targeting IL-17 alone is not sufficient to improve clinical end points in other autoimmune conditions, namely RA [34]. Targeting the Th17 cell lineage may show better anti-RA effects. We found that SF not only significantly decreased the number of Th17 cells in the spleen and lymph nodes of CIA mice, but it could also significantly inhibit the production of Th17 cells in vitro. RORyt is a key transcription factor that controls the differentiation of Th17 cells and induces the expression of genes encoding IL-17 and IL-17 F cytokines [35]. IL-6 can induce the upregulation of ROR $\gamma t$ expression, initiating the ROR $\gamma t$ signal transduction pathway to promote Th17 cell differentiation [36]. The promotion of Th17 differentiation by ROR $\gamma \mathrm{t}$ is mainly related to the phosphorylation of STAT3 [37]. 
Our results showed that SF can significantly decrease the expression levels of RORyt and pSTAT3 (Tyr705) in the spleen of CIA mice, and SF can also inhibit the expression levels of RORyt and pSTAT3 (Tyr705) in vitro. Furthermore, the expression of interferonregulatory cytokine 4 (IRF4) was also suppressed by SF. IRF4 is essential for the development of Th17 cells and mainly regulates the secretion of IL-17 and IL-21 [38]. These results suggest that SF inhibit the differentiation of Th17 cells by suppressing the expression of pSTAT3 (Tyr705) and ROR $\gamma$ t.

This study confirmed, for the first time, that SF could maintain immune balance by inhibiting Th17 cell differentiation, which indicates that SF is an alternative drug candidate for the treatment of RA.

\section{Conclusions}

In conclusion, our results suggest that SF exhibits antiarthritic effects and restores Th17/Treg homeostasis in CIA mice by inhibiting Th17 cell differentiation.

\begin{abstract}
Abbreviations
RA: Rheumatoid arthritis; CIA: Collagen-induced arthritis; SF: Soufeng sanjie formula; MTX: Methotrexate; HPLC: High performance liquid chromatography; HPLC-Q-TOF-MS: High performance liquid chromatography-quadrupole-timeof-flight mass spectrometry; TNF-a: Tumor necrosis factor-a; IL-6: Interleukin-6; IL-17: Interleukin-17; IL-10: Interleukin-10; ELISA: Enzyme-linked immunosorbent assay; IRF4: Interferon regulatory factor 4; RORyt: Retinoid-related orphan nuclear receptor yt; pSTAT3 (Tyr705): Phosphorylated STAT3(Tyr705).
\end{abstract}

\section{Supplementary Information}

The online version contains supplementary material available at https://doi. org/10.1186/s13020-021-00448-9.

Additional file 1. Effect of SF on Th1 and Th2 cells in the spleen of CIA mice.

\section{Acknowledgements}

Not applicable.

\section{Authors' contributions}

$\mathrm{CH}, \mathrm{PC}$ and JY designed the study; $\mathrm{DH}, \mathrm{YL}, \mathrm{QW}, \mathrm{XH}$ and $\mathrm{ZW}$ carried out the experiments; $\mathrm{DH}, \mathrm{QW}, \mathrm{JC}$ and JY performed the data analysis; WK, CX and KS provided manuscript preparation; DH, JY and QM wrote and revised the manuscript. All authors read and approved the final manuscript.

\section{Funding}

This study was supported by Jiangsu Academy of Traditional Chinese Medicine (BM2018024-2019003), the National Natural Science Foundation of China (No. 81773973), and Jiangsu Province Traditional Chinese Medicine Science and Technology Development Plan Project (YB2020016).

\section{Availability of data and materials}

The data used to support the findings of this study are available from the corresponding author upon request.

\section{Declarations}

Ethics approval and consent to participate

All procedures were performed in accordance with the guidelines of the Nanjing University of Chinese Medicine ethics committee.

\section{Consent for publication}

Not applicable.

\section{Competing interests}

The authors declare that they have no competing interests.

\section{Author details}

${ }^{1}$ Affiliated Hospital of Integrated Traditional Chinese and Western Medicine, Nanjing University of Chinese Medicine, Nanjing 210028, China. ${ }^{2}$ College of Pharmacy, Nanjing University of Chinese Medicine, Nanjing 210023, China. ${ }^{3}$ Affiliated Hospital of Yifu, Nanjing Medical University, Nanjing 211166, China.

Received: 3 March 2021 Accepted: 3 May 2021

Published online: 13 May 2021

\section{References}

1. Weyand CM, Goronzy JJ. The immunology of rheumatoid arthritis. Nat Immunol. 2021;22(1):10-8.

2. Sparks JA. Rheumatoid arthritis. Ann Intern Med. 2019;170(1):ITC1-16.

3. Ngo ST, Steyn FJ, McCombe PA. Gender differences in autoimmune disease. Front Neuroendocrinol. 2014;35(3):347-69.

4. Mclnnes IB, Schett G. Cytokines in the pathogenesis of rheumatoid arthritis. Nat Rev Immunol. 2007;7(6):429-42.

5. Mclnnes IB, Schett $G$. The pathogenesis of rheumatoid arthritis. N Engl J Med. 2011:8(23):2205-19.

6. Noack M, Miossec P. Th17 and regulatory T cell balance in autoimmune and inflammatory diseases. Autoimmun Rev. 2014;13(6):668-77.

7. Nie H, Zheng Y, Li R, Guo TB, He D, Fang L, Liu X, Xiao L, Chen X, Wan B, Chin YE, Zhang JZ. Phosphorylation of FOXP3 controls regulatory $T$ cell function and is inhibited by TNF-a in rheumatoid arthritis. Nat Med. 2013:19(3):322-8

8. Komatsu N, Okamoto K, Sawa S, Nakashima T, Oh-hora M, Kodama T, Tanaka S, Bluestone JA, Takayanagi H. Pathogenic conversion of Foxp3 ${ }^{+} \mathrm{T}$ cells into TH17 cells in autoimmune arthritis. Nat Med. 2014;20(1):62-8.

9. Hirota K, Hashimoto M, Ito Y, Matsuura M, Ito H, Tanaka M, Watanabe H, Kondoh G, Tanaka A, Yasuda K, Kopf M, Potocnik AJ, Stockinger B, Sakaguchi N, Sakaguchi S. Autoimmune Th17 cells induced synovial stromal and innate lymphoid cell secretion of the cytokine GM-CSF to initiate and augment autoimmune arthritis. Immunity. 2018;48(6):1220-1232.e5.

10. Smolen JS, Aletaha D, Barton A, Burmester GR, Emery P, Firestein GS, Kavanaugh A, McInnes IB, Solomon DH, Strand V, Yamamoto K. Rheumatoid arthritis. Nat Rev Dis Primers. 2018;8:18001

11. Kerschbaumer A, Sepriano A, Smolen JS, van der Heijde D, Dougados M, van Vollenhoven R, Mclnnes IB, Bijlsma JWJ, Burmester GR, de Wit M, Falzon L, Landewé R. Efficacy of pharmacological treatment in rheumatoid arthritis: a systematic literature research informing the 2019 update of the EULAR recommendations for management of rheumatoid arthritis. Ann Rheum Dis. 2020;79(6):744-59.

12. Smolen JS, Landewé RBM, Bijlsma JWJ, Burmester GR, Dougados M, Kerschbaumer A, Mclnnes IB, Sepriano A, van Vollenhoven RF, de Wit M, Aletaha D, Aringer M, Askling J, Balsa A, Boers M, den Broeder AA, Buch MH, Buttgereit F, Caporali R, Cardiel MH, De Cock D, Codreanu C, Cutolo M, Edwards CJ, van Eijk-Hustings Y, Emery P, Finckh A, Gossec L, Gottenberg JE, Hetland ML, Huizinga TWJ, Koloumas M, Li Z, Mariette X, Müller-Ladner U, Mysler EF, da Silva JAP, Poór G, Pope JE, Rubbert-Roth A, Ruyssen-Witrand A, Saag KG, Strangfeld A, Takeuchi T, Voshaar M, van der Westhovens $\mathrm{R}$, Heijde D. EULAR recommendations for the management of rheumatoid arthritis with synthetic and biological disease-modifying antirheumatic drugs: 2019 update. Ann Rheum Dis. 2020;79(6):685-99.

13. Smolen JS, Aletaha D, McInnes IB. Rheumatoid arthritis. Lancet. 2016;388(10055):2023-38. 
14. Lv QW, Zhang W, Shi Q, Zheng WJ, Li X, Chen H, Wu QJ, Jiang WL, Li HB, Gong L, Wei W, Liu H, Liu AJ, Jin HT, Wang JX, Liu XM, Li ZB, Liu B, Shen M, Wang Q, Wu XN, Liang D, Yin YF, Fei YY, Su JM, Zhao LD, Jiang Y, Li J, Tang FL, Zhang FC, Lipsky PE, Zhang X. Comparison of Tripterygium wilfordii Hook $F$ with methotrexate in the treatment of active rheumatoid arthritis (TRIFRA): a randomised, controlled clinical trial. Ann Rheum Dis. 2015;74(6):1078-86.

15. Zhong H, Zhao J. Clinical application of insect drugs. J Tradit Chin Med. 2003:23(4):257-9.

16. Liu DY, Zhao HM, Cheng SM, Rao Y, Huang XY, Zuo ZQ, Lei M, Guan YM, Liu HN, Lu AP. Scorpio and Scolopendra attenuate inflammation and articular damage in rats with collagen-induced arthritis. J Ethnopharmacol. 2012;141(2):603-7.

17. Liu XY, Xu L, Wang Y, Li JX, Zhang Y, Zhang C, Wang SS, Zhang XM. Protective effects of total flavonoids of Astragalus against adjuvant-induced arthritis in rats by regulating OPG/RANKL/NF-KB pathway. Int Immunopharmacol. 2017:44:105-14.

18. Min HK, Kim SM, Baek SY, Woo JW, Park JS, Cho ML, Lee J, Kwok SK, Kim SW, Park SH. Anthocyanin extracted from black soybean seed coats prevents autoimmune arthritis by suppressing the development of Th17 cells and synthesis of proinflammatory cytokines by such cells, via inhibition of NF-kB. PLoS ONE. 2015;10(11):e0138201.

19. Liu XD, Zhang JL, Ye LH. Effects of wenhua juanbi recipe on TNF-alpha and IL-1 beta in peripheral blood of rheumatoid arthritis patients. Zhongguo Zhong Xi Yi Jie He Za Zhi. 2009;29(9):787-90.

20. Zheng H, Qiu F, Zhao H, Chen J, Wang L, Zou H. Simultaneous determination of six bioactive saponins from Rhizoma Panacis Japonici in rat plasma by UHPLC-MS/MS: application to a pharmacokinetic study. J Chromatogr B Analyt Technol Biomed Life Sci. 2018;1092:199-206. (Epub 2018 Jun 7).

21. Zhou L, Wang J, Li J, Li T, Chen Y, June RR, Zheng SG. 1,25-Dihydroxyvitamin D3 ameliorates collagen-induced arthritis via suppression of Th17 cells through miR-124 mediated inhibition of IL-6 signaling. Front Immunol. 2019;7:178

22. Wu H, Chen J, Song S, Yuan P, Liu L, Zhang Y, Zhou A, Chang Y, Zhang L, Wei W. $\beta 2$-adrenoceptor signaling reduction in dendritic cells is involved in the inflammatory response in adjuvant-induced arthritic rats. Sci Rep. 2016;6:24548

23. Moon SJ, Park JS, Woo YJ, Lim MA, Kim SM, Lee SY, Kim EK, Lee HJ, Lee WS, Park SH, Jeong JH, Park SH, Kim HY, Cho ML, Min JK. Rebamipide suppresses collagen-induced arthritis through reciprocal regulation of th17/treg cell differentiation and heme oxygenase 1 induction. Arthritis Rheumatol. 2014;66(4):874-85.

24. Corson TW, Crews CM. Molecular understanding and modern application of traditional medicines: triumphs and trials. Cell. 2007;130(5):769-74.

25. Xue T, Roy R. Studying traditional Chinese medicine. Science. 2003;300(5620):740-1.
26. Chen Z, Bozec A, Ramming A, Schett G. Anti-inflammatory and immuneregulatory cytokines in rheumatoid arthritis. Nat Rev Rheumatol. 2019:15(1):9-17.

27. Ohshima S, Saeki Y, Mima T, Sasai M, Nishioka K, Nomura S, Kopf M, Katada Y, Tanaka T, Suemura M, Kishimoto T. Interleukin 6 plays a key role in the development of antigen-induced arthritis. Proc Natl Acad Sci USA. 1998;7(14):8222-6.

28. Ouyang W, Kolls JK, Zheng Y. The biological functions of T helper 17 cell effector cytokines in inflammation. Immunity. 2008:28(4):454-67.

29. Chaudhry A, Samstein RM, Treuting P, Liang Y, Pils MC, Heinrich JM, Jack RS, Wunderlich FT, Brüning JC, Müller W, Rudensky AY. Interleukin-10 signaling in regulatory $T$ cells is required for suppression of Th17 cellmediated inflammation. Immunity. 2011;34(4):566-78.

30. Zhu J, Yamane H, Paul WE. Differentiation of effector CD4 T cell populations. Annu Rev Immunol. 2010;28:445-89.

31. Peck A, Mellins ED. Breaking old paradigms: Th17 cells in autoimmune arthritis. Clin Immunol. 2009;132(3):295-304.

32. Hsu HC, Yang P, Wang J, Wu Q, Myers R, Chen J, Yi J, Guentert T, Tousson A Stanus AL, Le TV, Lorenz RG, Xu H, Kolls JK, Carter RH, Chaplin DD, Williams RW, Mountz JD. Interleukin 17-producing Thelper cells and interleukin 17 orchestrate autoreactive germinal center development in autoimmune BXD2 mice. Nat Immunol. 2008;9(2):166-75.

33. Littman DR, Rudensky AY. Th17 and regulatory T cells in mediating and restraining inflammation. Cell. 2010;140(6):845-58.

34. Yang J, Sundrud MS, Skepner J, Yamagata T. Targeting Th17 cells in autoimmune diseases. Trends Pharmacol Sci. 2014;35(10):493-500.

35. Ivanov II, McKenzie BS, Zhou L, Tadokoro CE, Lepelley A, Lafaille JJ, Cua DJ, Littman DR. The orphan nuclear receptor RORgammat directs the differentiation program of proinflammatory IL-1 $7^{+}$Thelper cells. Cell. 2006;126(6):1121-33

36. Basso AS, Cheroutre H, Mucida D. More stories on Th17 cells. Cell Res. 2009;19(4):399-411.

37. Yang XO, Panopoulos AD, Nurieva $R$, Chang SH, Wang D, Watowich SS, Dong C. STAT3 regulates cytokine-mediated generation of inflammatory helper T cells. J Biol Chem. 2007;282(13):9358-63.

38. Staudt V, Bothur E, Klein M, Lingnau K, Reuter S, Grebe N, Gerlitzki B, Hoffmann M, Ulges A, Taube C, Dehzad N, Becker M, Stassen M, Steinborn A, Lohoff M, Schild H, Schmitt E, Bopp T. Interferon-regulatory factor 4 is essential for the developmental program of T helper 9 cells. Immunity. 2010;27(2):192-202

\section{Publisher's Note}

Springer Nature remains neutral with regard to jurisdictional claims in published maps and institutional affiliations.
Ready to submit your research? Choose BMC and benefit from:

- fast, convenient online submission

- thorough peer review by experienced researchers in your field

- rapid publication on acceptance

- support for research data, including large and complex data types

- gold Open Access which fosters wider collaboration and increased citations

- maximum visibility for your research: over 100M website views per year

At BMC, research is always in progress.

Learn more biomedcentral.com/submissions 